\title{
Subtype Identification Of Avian Influenza Virus Isolated from Laying Duck In Sidenreng Rappang, South Sulawesi With Hemagglutination Inhibition Assay
}

\author{
$\underline{\text { Bagus Nanang Luwito }}^{1,2, a)} *$, Ahmad Nadif ${ }^{1,3, b)}$, Retno D Soejoedono ${ }^{4, c)}$, I Wayan T \\ Wibawan $^{4, \mathrm{~d})}$ \\ ${ }^{1}$ Graduate School of IPB, Bogor Agricultural University \\ Jl. Agatis, Kampus IPB Dramaga, Bogor \\ ${ }^{2}$ Agricultural Qarantine Agency, Ministry Agriculture Republic of Indonesia \\ Jl. Harsono RM Nomor 3 Ragunan, Pasar Minggu Jakarta 12550 Grdung E Lt.1, 5, 7 \\ ${ }^{3}$ Pare - pare Agricultural Quarantine Unit of South Sulawesi \\ JL Tarakan, No. 1, Cappa Ujung, Parepare, Sulawesi Selatan 91114, Indonesia \\ ${ }^{4}$ Departemen of Animal Diseases and Veterinary Public Health, Faculty of Veterinary \\ Medicine, \\ Jl. Agatis, Kampus IPB Dramaga, Bogor \\ ${ }^{\text {a)} C o r r e s p o n d i n g ~ a u t h o r: ~ b a g u s 240456 @ g m a i l . c o m ~}$ \\ b)ahmadnadif1981@gmail.com \\ c)retnodmail@yahoo.com \\ d)wibawan@yahoo.com
}

\begin{abstract}
Avian Influenza virus (AIV) have caused significant economic losses in poultry sector worldwide. Results of genetic mapping showed that circulating AIV in Indonesia were belong to clade 2.1.1, 2.1.2, 2.1.3 and 2.3.2, however the AIV subtype were merely H5N1.Our study aim to identify the hemagglutinin protein of AIV isolated from native laying duck in Sidenreng Rappang, South Sulawesi, Indonesia using HI assay. Three cloacal swab samples:Sidrap3 (S3), Sidrap5 (S5), and Sidrap10 (S10) were isolated from native laying duck at three duck farms at Sidenreng Rappang during AI outbreaks in 2016. These samples were propagated on spesific antibody negative (SAN) embryonated chicken eggs, followed by subtype identification using hemagglutination inhibition (HI) test using specific antibody of AIV subtype H5N1, AIV subtype H5N2, AIV subtype H5N3 and ND Lasota virus. Our study showed that H5N1 specific antibody has titer of $2^{4}$ against virus isolates Sidrap3 and Sidrap10, titer of $2^{6}$ against virus isolates Sidrap5. H5N2 specific antibody has titer $2^{4}$ against virus isolates Sidrap3 and Sidrap5, titers of $2^{6}$ against virus isolates Sidrap10. H5N3 specific antibody has titers of $2^{6}$ against virus isolates Sidrap3, Sidrap5 and Sidrap10. Whilst, specific antibody of ND Lasota did not react with all of virus isolates. Our results showed that all AIV isolates gives highest reaction with specific antibody of AIV H5N3. According to the result, it is likely that AIV H5N3 might circulating among laying duck in Sidenreng Rappang.
\end{abstract}

Keywords: avian influenza, subtype, hemagglutination inhibition, Sidenreng Rappang 


\section{INTRODUCTION}

Avian Influenza Virus (AIV) outbreaks have caused significant economic losses in poultry sector worldwide.Since 1997, Asian lineage highly pathogenic AIV (H5N1) has spread from Asia to Europe, the Middle East and Africa (Bragstad et al. 2007). The virus has been associated with significant mortality in wild bird (Uchida et al. 2008). Furthermore, humans and some other species of mammals have contracted the disease by close contact with infected bird (Hayden and Croisier 2005; Songserm et al. 2006).

AIV is a lipid-envelope virus of the family Orthomyxoviridae and genus Influenzavirus A. Type A influenza viruses can be divided into 16 hemaglutinin (HA; H1-H16) and nine neuraminidase (NA; N1-N9) subtypes based on the genetic sequence for the envelope protein (Spackman 2008), although in 2012 it has been found H17N10 type A influenza virus isolated from bats (Tong et al. 2012). The hemagglutinin protein on the surface of type A influenza virus particles is capable of binding to $\mathrm{N}$-acetylneuraminic acid-containing protein on avian and mamalian erythrocites (Killian 2008). Aglutination of erythrocites is the basis of the hemaglutination (HA) assay, and inhibition of the aglutination reaction by subtypespecific antisera is the basis of the hemaglutinition inhibition (HI) assay (Pedersen 2008).

Results of genetic mapping showed that circulating AIV in Indonesia were belong to clade 2.1.1, 2.1.2, 2.1.3 and 2.3.2(.Dharmayanti et al. 2013), however the AIV subtype were merely H5N1.Since its first outbreak in Indonesia in late 2003 until mid 2012, AIV caused morbidity and mortality in chickens, whilst duck were considered as reservoir. However, in late 2012, there is AIV outbreak among commercial duck in Central Java, this incident proves that duck were also susceptible of AIV. AIV which infected duck were belong to subtype H5N1 clade 2.3.2 (Wibawa et al. 2012). After its introduction of new AIV clade 2.3.2, this clade has been spread to other regions in Indonesia. Some epidemological studies revealed that free-range domestic ducks played a prominent role in regional spread of AIV H5N1 in Suotheast Asia. Asymtomatically infected domestic ducks can sheed the virus continuously from their oral cavity and cloaca, contributing significantly to silent spread of AIV H5N1 (Songserm et al. 2006).

Recently, AIV identification were determined using molecular technique such as RT-PCR and nucleotide sequence. These technique enabled us to identify pathogen to the species, strain and clade. However, conventional technique as HI assay were still considered as standard test for AIV identification (OIE 2015).Our study aim to identify the hemagglutinin protein of AIV isolated from native laying duck in SidenrengRappang, South Sulawesi, Indonesia using $\mathrm{HI}$ assay. Result of this research might be useful as first infomation AIV subtype for genetic analysis.

\section{MATERIAL AND METHOD}

\section{Samples}

Three cloacal swab samples:Sidrap3 (S3), Sidrap5 (S5), and Sidrap10 (S10) were isolated from native laying duck at three duck farms at SidenrengRappang during AI outbreaks in 2016. 


\section{Isolation and Propagation Virus}

Each swab samples were propagated in three embryonatedSpecific Antibody Negative (SAN) chicken eggs on 9 day old, each egg were inoculated with $0.2 \mathrm{ml}$ swab medium, after 60 hours (h), or when the embryo died before that time, the allantois fluid was harvested. Allantois fluid were tested using HA assay following standard procedure (OIE 2015).

\section{Hemaglutination Assay}

HA tests were performed by combining $50 \mu$ l chorioallantoic fluid (CAF) from one egg and $50 \mu 1$ chiken red blood cells (CRBCs) $5 \%$. The mixture of CAF and CRBCs was gently agigate for 15 to 30 second. A positif result with aglutination indicate the presence of the AIV in the CAF sample tested. The HA test was performed on each egg individually.

\section{Hemaglutination Inhibition Assay}

AIV subtype identification were determined using HI assay. Four specific antibody of AIV H5N1, AIV H5N2, AIV H5N3 and Newcastle diseases virus (NDV) Lasota were used for HI assay. The HI tests were carried out using 4 HAU of the AIV isolates. The serum samples were made into two fold dilution, and the titer were expressed as the reciprocal of the last serum dilution that caused complete inhibition of agglutination (OIE 2015)

\section{RESULTS}

\section{Virus Titer}

All AIV isolates showed virus positive. Results of virus HA titre were presented in Table 1.

TABLE 1. Virus titer

\begin{tabular}{cc}
\hline Isolat & HA titers $($ HAU)* \\
\hline \hline Dk/Sidrap/(S3)/2016 & $2^{10}$ \\
\hline Dk/Sidrap/(S5)/2016 & $2^{9}$ \\
\hline Dk/Sidrap/(S10)/2016 & $2^{11}$ \\
\hline
\end{tabular}

*HA titer were presented in $\log 2$ 


\section{Virus-specific Antibody Reaction}

AIV subtypeidentification were determined using HI assay using specific antibody of AIV H5N1, AIV H5N2, AIV H5N3 and NDVLasota, the result were presented in Table 2.

TABLE 2.Virus-specific antibody reaction

\begin{tabular}{ccccc}
\hline \multirow{2}{*}{ Sample } & \multicolumn{4}{c}{ HI titre (Log2) } \\
\cline { 2 - 5 } & H5N1 & H5N2 & H5N3 & $\begin{array}{c}\text { ND } \\
\text { Lasota }\end{array}$ \\
\hline \hline $\begin{array}{c}\text { Dk/Sidrap/(S3)/201 } \\
6\end{array}$ & $2^{4}$ & $2^{4}$ & $2^{6}$ & $<2^{1}$ \\
\hline $\begin{array}{c}\text { Dk/Sidrap/(S5)/201 } \\
6\end{array}$ & $2^{6}$ & $2^{4}$ & $2^{6}$ & $<2^{1}$ \\
\hline $\begin{array}{c}\text { Dk/Sidrap/(S10)/20 } \\
16\end{array}$ & $2^{4}$ & $2^{6}$ & $2^{6}$ & $<2^{1}$
\end{tabular}

\section{DISCUSSION}

The AIV is type A influenza isolated from andadapted to avian host. Type A influenzabelongs to the orthomyxovirdae virus family, is enveloped, and pleiomorphic with a size ranging from 80-120 nm.Type A influenza strains are classified by the serological subtypes of the primary viral surface proteins, the HAand NA. With a new serotype (H17) of hemagglutinin recently being discovered, there are now 17 serotypes (H1 to H17) of influenza A viruses in total (Tong et al. 2012). There are currently 17 HA subtypes (H1 to H17) and 10 NA subtypes (N1 to N10) known.16 subtypes have been found in ducks, gulls, or shore birds, the natural reservoir host species of the virus. However, in these species certain subtypes are more common than others; for example, H3, H4, and $\mathrm{H} 6$ are most common in ducks in North America and although there is no clear association between host range or host restriction based on HA subtype, some subtypes are more common in some species than others, for example $\mathrm{H} 1$ and $\mathrm{H} 3$ in swine, $\mathrm{H} 3$ in horses, and $\mathrm{H} 5$ and $\mathrm{H} 7$ in chickens(Spackman 2008), and new virus genome subtype H17 identified from bat (Tong et al. 2012).

The rapid detection and diagnosis of AI virus in poultry, wild birds, and other species are critical to controle the virus. Subsequent characterization provides vital information about the ecology and biology of the virus. Because of the clinical importance of the presence of a viable virus isolate, and the necessityof having a virus isolates to characterized, virus isolation is probably the most critical of these methods .Classical methods such as HI assay, neuraminidase inhibition assay, and in vivo pathotyping are still the reference standards required.

Inhibition of RBCs agglutination in HI assay were caused by antigen-antibody bond. Influenza virus membranes contain two subtype spesific glycoprotein which is hemagglutinin (HA) and neuraminidase (NA) on their surface envelope. Hemagglutinin mediates cell surface sialic acid receptor binding to initiate virus infection, while neuraminidase play role on biological activity in removing $\mathrm{N}$-acetyl neuraminic acid or sialic acid from sugar chain of glycoprotein and as major antigenic determinant (Pedersen 2008).

In the current study, we aim to identify hemagglutinin protein of AIV isolates. Our result showed that all isolates were able to react with spesific antibody of AIV H5N1, AIV H5N2 and AIV H5N3, but did not react with spesific antibody of NDV Lasota. This result indicated that all AIV isolates were belong to H5 subtype. In diagnostic assay, an AIV with novel hemagglutinin subtype would not be produce a false-negative result in HI assay using a known HA subtypes spesific antibody. However, usage of NA subtype specific antibody will 
help to avoid false-positive reaction on identification using HI assay. When the NA subtype is unknown, it is necessary to perform HI assay with several NA subtypes spesific antibody since it will help to eliminate false-positive result due to steric inhibition from the NA antibody (Pedersen 2008).

Our results also showed that all AIV isolates gives highest reaction with specific antibody of AIV H5N3. According to the result, it is likely that AIV H5N3 might circulating among laying duck in Sidenreng Rappang. However, in the current study, we only performed HI assay for subtype determination, we realize that more general statement need another assay such as reverse transcriptase-polymerase chain reaction (RT-PCR) and nucleotide sequence to be done. However, we did not performed other assay since it is beyond our purpose of study. Therefore we cannot give a strong conclusion based only HI assay result. Nevertheless, our result were in accordance with previous study of Susanti (2008) which is able to isolated AIV subtype H5Nx from native duck in West Java indicating that there might be other than N1 exist. A continuous surveillance of AIV in Indonesia are needed to understand the evolution, genetic and antigenic character of circulating virus. For better surveillance result, characterization of AIV should be done up to identifying HA and NA subtype.

\section{REFERENCES}

1. E. Spackman, A Brief Introduction to the Avian Influenza Virus, In: Methods in Molecular Biology :Avian Influenza Virus, edited by E. Spackman (HumanaPress, 999 Riverview Drive, Suite 208, Totowa, NJ 07512 USA 2008), pp. 1-6

2. F. Hayden, and A. Croisier. Transmission of avian influenza viruses to and between humans. J. Infect. Dis. 192:1311-1314. (2005).

3. H. Wibawa, W. B. Prijono, N. L. P. I. Dharmayanti, S. H .Irianingsih, Y. Miswati, A.Rohmah, EAndesyha, Romlah, R. S. D.Daulay, K. Safitria, Investigasi wabah penyakit pada itik di Jawa Tengah, Yogyakarta, dan JawaTimur: Identifikasi sebuah clade baru virus avian influenza subtipe H5N1 di Indonesia. Bul Lab Vet. 12:2-9. (2012)

4. J. C. Pedersen, Hemagglutination-Inhibition Test for Avian Influenza Virus Subtype Identification and the Detection and Quantitation of Serum Antibodies to the Avian Influenza Virus, In: Methods in Molecular Biology :Avian Influenza Virus, edited by E. Spackman (HumanaPress, 999 Riverview Drive, Suite 208, Totowa, NJ 07512 USA 2008), pp. 53-66

5. K. Bragstad, P. H. Jørgensen, K. Handberg, A. S. Hammer, S. Kabell, and A. Fomsgaard. First introduction of highly pathogenic H5N1 avian influenza A viruses in wild and domestic birds in Denmark, Northern Europe.Virol. J. 4:43. (2007)

6. M. L. Killian, Heamgglutination Assay for the Avian Influenza Virus, In: Methods in Molecular Biology :Avian Influenza Virus, edited by E. Spackman (HumanaPress, 999 Riverview Drive, Suite 208, Totowa, NJ 07512 USA 2008), pp. 47-52

7. N.L.P.I.Dharmayanti, R.Hartawan, D. A.Hewajui, Hardiman, H.Wibawa, Pudjiatmoko..KarakteristikMolekulerdanPatogenesitas Virus H5N1 Clade 2.3.2 asal Indonesia. JurnalIlmuTernakdanVeteriner 18(2):99-113 (2013)

8. [OIE] Office International des Epizooties, Avian Influenza, In: Manual of Diagnostic Test and Vaccines for Terrestial Animals, 7th ed., chapter 2.3.4., 2, http://www.oie.int/international-standard-setting/terrestrial-manual/access-online/pdf ( 2015)

9. R.Susanti, R. D Soejoedono, I. G. N. K. Mahardika, I. W. T Wibawandan M. T.Suhartono,Potensi Unggas Air sebagai Reservoir Virus High Pathogenic Avian Influenza Subtipe H5N1, JITV 12 (2), pp. 160-166(2007)

10. S.Tong, et al. . A distinct lineage of influenza A virus from bats. Proc. Natl. Acad. Sci. U. S. A. 109:4269-4274. (2012) 
11. T. Songserm, , R. Jam-on, N. Sae-Heng, N. Meemak, D. J. Hulse-Post, K. M. SturmRamirez, and R. G. Webster, Domestic ducks and H5N1 influenzaepidemic, Thailand. Emerg. Infect. Dis. pp:575-581. (2006)

12. Y.Uchida, M. Mase, K. Yoneda, A. Kimura, T. Obara, S. Kumagai, T. Saito, Y. Yamamoto, K. Nakamura, K. Tsukamoto, and S. Yamaguchi. Highly pathogenic avian influenza virus (H5N1) isolated from whooper swans, Japan. Emerg. Infect. Dis. 14:1427-1429. (2008) 